\title{
APPLYING THE INTERNATIONAL LAW OF SOVEREIGN IMMUNITY TO THE STATES OF THE UNION
}

\author{
JOHN M. ROGERS*
}

A state of the Union nray preserve its immunity from suit in its own courts, and the Constitution restricts its amenability to suit in the federal courts. ${ }^{1}$ Yet in Nevada v. Hall $^{2}$ the Supreme Court held that in a motor-vehicle accident case a state cannot clann a constitutional immunity from suit im the courts of a sister state. ${ }^{3}$ The Court imdicated, however, that if a suit involved a defendant state's "capacity to fulfill its own sovereign responsibilities," different constitutional considerations might control. ${ }^{4}$ In vigorous dissents Justices Blackmun 5 and Rehnquist ${ }^{6}$ argned that the reasoning of the majority precluded even this possibility. Justice Rehnquist suggested that im making such distimctions in the future, the Court would be "truly adrift on uncharted waters." 7 It may be, however, that there already is a chart to these waters, discoverable fron the majority's reasoning though not obvious from the opmion. That chart is the international law of sovereign immunity. ${ }^{8}$

* Associate Professor of Law, University of Kentucky College of Law. B.A. 1970, Stanford University; J.D. 1974, University of Michigan.

1. The eleventh amendment provides: "The Judicial Power of the United States shall not be construed to extend to any suit in law or equity, commenced or prosecuted against one of the United States by Citizens of another State, or by Citizens or Subjects of any Foreign State." U.S. Const. amend. XI. Most states have statutorily waived or limited their immunity in their own courts. See 10 CUM. L. REv. 579, 586-87 nn.49-53 (1979).

2. 440 U.S. 410 (1979).

3. For other commentary on Nevada v. Hall, see Martin, The New Interpretation of Sovereign Immunity for the States, 16 CAL. W.L. REv. 39 (1980); Stewart, The State as Unwilling Defendant: Reflections on Nevada v. Hall, 59 NEB. L. REv. 246 (1980); The Supreme Court, 1978 Term, 93 HARv. L. Rev. 1, $189-98$ (1979); Comment, The Abolition of Sister State Immunity: Nevada v. Hall and Territorial Sovereignty, 69 B.U.L. Rev. 601 (1980); Note, Nevada v. Hall: The Death Knell of Interstate Sovereign Immunity, 9 CAP. U.L. REv. 113 (1979); Comment, Nevada v. Hall: Sovereign Immunity, Federalism and Compromising Relations Between Sister States, 1980 UtaH L. Rev. 395; 48 U. Cin. L. Rev. 1069 (1979); 58 WASH. U.L.Q. 481 (1980).

4. 440 U.S. at 424 n.24.

5. Id. at 429 (Blackmun, J., dissenting).

6. Id. at $442-43$ (Rehnquist, J., dissenting).

7. Id. at 443 .

8. Despite early predictions that suits against states in courts of other states will be rare, see, e.g., The Supreme Court, 1978 Term, supra note 3, at 198; Comment, supra note 3, 1980 UTAH L. REv. at 404, increasing numbers of such cases can be expected because of the Supreine Court's 


\section{NEVADA V. HALL}

In Nevada v. Hall ${ }^{9}$ three California residents were injured when their car collided in California with a car owned by the State of Nevada. The driver of the Nevada car was an einployee of the University of Nevada, an official arm of the State of Nevada; he was concededly engaged in university business at the time of the accident. ${ }^{10}$ The plaintiffs sued the driver's estate, the University, and the State of Nevada in the California courts. ${ }^{11}$ The state and the university were served with process pursuant to the California long-arm statute for out-of-state drivers. ${ }^{12}$ The trial court quashed service on the state defendants, but the Supreme Court of California reversed and remanded for trial, holding that the State of Nevada could be sued in California courts. ${ }^{13}$ The court reasoned that when one state engages in activities in another state, it is not exercising sovereign power over the citizens of the second state and thus cannot assert sovereign immunity in the courts of the second state unless the second state confers that right. ${ }^{14}$ In denying

decision in Nevada v. Hall. Since Nevada v. Hall three such cases have reached state high courts: Chavez v. Indiana, 122 Ariz. 560, 596 P.2d 698 (1979) (the court found no personal jurisdiction over the state and thus did not reach the sovereign immunity issue); Carlson Corp. v. University of Vermont, 1980 Mass. Adv. Sh. 659, 402 N.E.2d 483 (1980) (the court denied immunity to a state on a claim arising out of a construction contract dispute); Ehrlich-Bober \& Co. v. University of Houston, 49 N.Y.2d 574, 404 N.E.2d 726, 427 N.Y.S.2d 604 (1980) (a state has no immunity, even as a matter of comity, when the transaction arose from a securities repurchase agreement).

9. 440 U.S. 410 (1979).

10. Id. at 411 .

11. Id. at 411-12.

12. CAL. Veh. CODE $\S 17451$ (West 1971); 440 U.S. at $412 \&$ n.1.

13. Hall v. University of Nevada, 8 Cal. 3d 552, 503 P.2d 1363, 105 Cal. Rptr. 355 (1972), cert. denied, 414 U.S. 820 (1973). See generally Martiniak, Hall v. Nevada: State Court Jurisdiction Over Sister States v. American State Sovereign Immunity, 63 CALIF. L. REv. 1144 (1975); Note, Hall v. University of Nevada: Sovereign Immunity and the Transitory Action, 27 ARK. L. Rev. 546 (1973); Note, Sovereign Immunity—May a State Assert In Personam Jurisdiction over a Sister State Without Its Consent?, 53 B.U.L. Rev. 736 (1973).

14. $8 \mathrm{Cal}$. 3d at 524-25, 503 P.2d at 1364-65, $105 \mathrm{Cal}$. Rptr. at 356-57. For this conclusion the court rehed on Parden v. Terminal Ry., 377 U.S. 184 (1964), which held that Alabama could be sued in a federal court under the Federal Employer's Liability Act, 45 U.S.C. $\$ \S 51-60$ (1976), despite the eleventh amendment, for imjuries sustained by an employee of Alabama's state-owned railway, 8 Cal. 3d at 524, 503 P.2d at 1364, 105 Cal. R.ptr. at 356. The Parden Court had reasoned that by operating a railroad in interstate commerce after the enactment of the FELA, Alabama had waived its immunity. 377 U.S. at 192. The Parden Court had also, however, relied hcavily on the federal regulatory power the states gave to Congress under the commerce clause in ratifying the Constitution. Id . at 190-92. Since Nevada had given no comparable power to California, the Califormia court's rehance on Parden is subject to the criticisn that the considerations of federal power present in Parden have no apphicability in the Nevada v. Hall situation: Martiniak, supra note 13, at 1146-47. Moreover, the waiver aspect of the Parden case has been narrowed in later Supreme Court eleventh amendment cases. See Employees v. Missouri Dep't of Pub. Health \& Welfare, 411 U.S. 279, 284-86 (1973) (upholding immunity and distinguishing Parden on grounds other than waiver); Id. at 299-308 (Brennan, J., dissenting on the basis of Parden); Field, The 
that comity required a grant of immunity to Nevada, the court held that other policies ${ }^{15}$ outweighed the policy of avoiding embarrassment to a sister state.

On remand the trial court found the Nevada driver negligent and awarded $\$ 1.15$ million in damages. ${ }^{16}$ Nevada appealed, arguing that the damages should have been limited to the $\$ 25,000$-per-claimant ceiling in the Nevada statute waiving Nevada's immunity in the Nevada courts. ${ }^{17}$ The California Court of Appeals rejected this argunient, stating that the California Supreme Court had permitted the suit against Nevada to go forward based not on the Nevada waiver statute but rather on the principle that "Nevada's sovereign protection does not extend beyond its own borders." 18 The court of appeals also rejected arguments that the $\$ 25,000$ limit should apply under the "full faith and credit" clause of the United States Constitution ${ }^{19}$ or under California conflict-of-laws rules. ${ }^{20}$ After the California Supreme Court's denial of review, the United States Supreme Court granted certiorari ${ }^{21}$ and affirmed the judgment of the California Court of Appeals. ${ }^{22}$

Justice Stevens's opmion, which five justices joined, ${ }^{23}$ noted at the outset that any federal rule restrictimg Califorina's exercise of jurisdiction "must be a part of the United States Constitution."24 Before beginning its constitutional inquiry, the Court distinguished two types of sovereign immunity: immunity in the sovereign's own courts (domestic immunity), and immunity in the courts of another sovereign (inter-

Eleventh Amendment and Other Sovereign Immunity Doctrines: Congressional Imposition of Suit upon the States, 126 U. PA. L. REv. 1203, 1209-10, 1213-18, 1235-37 (1978); Martiniak, supra note 13 , at 1147 .

15. These policies included the interest in providing a forum for a resident to seek redress, the interest in assuming jurisdiction when most of the evidenee is within California's borders, the anomaly of precluding an action against Nevada when California would have been amenable to suit had it been involved, and the suspect nature of the doctrine of sovereign immunity. $8 \mathrm{Cal} .3 \mathrm{~d}$ at 525-26, 503 P.2d at 1365-66, $105 \mathrm{Cal}$. Rptr. at 357-58.

16. See 440 U.S. at 413.

17. See Hall v. University of Nevada, 74 Cal. App. 3d 280, 283, 141 Cal. Rptr. 439, 440 (1977), aff' sub nom. Nevada v. Hall, 440 U.S. 410 (1979).

18. $74 \mathrm{Cal}$. App. 3d at 284, $141 \mathrm{Cal}$. Rptr. at 440.

19. U.S. CoNST. art. IV, \& 1, which provides: "Full Faith and Credit shall be given in each State to the public Acts, Records, and judicial Proceedings of every other State. And the Congress Inay by general Laws prescribe the Manner in which such Acts, Records and Proceedings shall be proved, and the Effect thereof."

20. 74 Cal. App. 3d at 285-86, 141 Cal. Rptr. at $441-42$.

21. 436 U.S. 925 (1978).

22. 440 U.S. at 427.

23. The five were Justices Brennan, Stewart, White, Marshall, and Powell. Id. at 411.

24. $I d$. at $414 \mathrm{n} .5$. 
sovereign-i.e., interstate or international-immunity). ${ }^{25}$ The Court, quoting Justice Holmes, found support for doinestic immunity "on the logical and practical ground that there can be no legal right as against the authority that makes the law on which the right depends."26 This explanation did not, however, support the immunity of a sovereign in the courts of a sister sovereign. ${ }^{27}$ Instead, the Court concluded that such immunity exists only if granted by the law of the forum sovereign. ${ }^{28}$ This conclusion relicd on the seminal international immunity case, The Schooner Exchange v. McFaddon ${ }^{29}$

In The Schooner Exchange the Court had held that United States law controlled whether France could assert sovereign immunity in American courts. Justice Stevens analogized that California law would control the question whether Nevada could assert immunity froin suit in California courts. ${ }^{30}$ Because California law clearly did not accord immunity to Nevada, the Court turned to whether the federal Constitution required California to recognize interstate immunity. ${ }^{31}$

Interstate immunity, according to the Court, unlike the immunity of states in the federal courts, was not considered when the Constitution was drafted and ratified. ${ }^{32}$ Moreover, the significant controversies over state immunity, represented by the cases of Chisholm $v$. Georgia, ${ }^{33}$ Hans v. Louisiana, ${ }^{34}$ and Monaco v. Mississippi ${ }^{35}$ and the enactment of

25. Id. at 414-18. Domestic sovereign immunity includes, in the context of a federal system, immunity of a state in that state's courts, immunity of the state in the fcderal courts, and immunity of the federal government in either state or federal court.

26. Id. at 415-16 (quoting Kawananakoa v. Polyblank, 205 U.S. 349, 353 (1907)).

27. 440 U.S. at 416.

28. Id. at $416-17$.

29. 11 U.S. (7 Cranch) 116 (1812).

30. 440 U.S. at 417.

31. Id. at $417-18$.

32. Id. at 418-19.

33. 2 U.S. (2 Dall.) 419 (1793). Chisholm v. Georgia held that Georgia eould be sued in federal court by a citizen of another state because of article III's grant of jurisdiction over controversies between a "State and Citizens of another State." The eleventh amendment, which was ratified in direct response to Chisholm, precluded the construction of the federal judicial power to extend to suits against states brought by citizens of other states or foreign nations. The amendment has been interpreted as rejecting the Chisholm Court's view of article III and restoring to the states the common-law sovereign immunity the Chisholm Court had hcld they had given up. See generally D. CuRRIE, Federal Courts 559-63 (1975); C. JACOBS, The EleVENTH AMENDMENT AND SOVEREIGN IMMUNITY 46-110 (1972); Baker, Federalism and the Eleventh Amendment, $48 \mathrm{U}$. CoLo. L. REv. 139 (1977); Field, The Eleventh Amendment and Other Sovereign Immunity Doctrines: Part One, 126 U. PA. L. REv. 515 (1977).

34. 134 U.S. 1 (1890). In Hans the Supreme Court held that even though the eleventh amendment did not expressly immunize states from suits by their own citizens, the amendment's overruling of Chisholm required construing the Constitution as leaving the states their sovereign immunity, even in a federal-question suit brought by a citizen against his own state in federal court. Id. at 10-19.

35. 292 U.S. 313 (1934). In Monaco the Court hcld that a state may not be sued by a foreign 
the eleventh amendment, all concerned the scope of authority of the federal courts to hear suits against states. These cases thus explored the power that states gave to federal courts when ratifying the Constitution, not the power of states to subject other states to suit. ${ }^{36}$

The Court also rejected Nevada's argument that the full faith and credit clause demanded that California apply Nevada's $\$ 25,000$ damage limit. ${ }^{37}$ Reaffirming settled law, the Court stated that when one state's law furthers a legitimate public policy, the full faith and credit clause does not compel that state to surrender the application of its law in favor of a second state's law that would control if the case were brought in the second state's court. ${ }^{38}$ Because California had a legitimate interest in fully coinpensating those persons injured on its highways, the full faith and credit clause did not require California to apply the Nevada damage limit. ${ }^{39}$

Finally, the Court considered the theory that the Constitution includes an unexpressed principle that states shall reinain free froin suit in the courts of other states. In forming a single nation, Nevada argued, the states tacitly agreed to honor one another's sovereignty. ${ }^{40} \mathrm{Al}-$ though recognizing that the states comprise a umion of entities of limited sovereignty, the Court hesitated to go beyond the exphicit constitutional limits on state power and impose a new implicit limit.41 To do so "would constitute the real intrusion on the sovereignty of the States-and the power of the people-in our Union."42 The Court thus concluded that if one state grants immunity to another, it does so purely as a matter of comity. ${ }^{43}$

In a footnote to its discussion of full faith and credit, the Court raised the possibility that its analysis might be limited to cases that pose "no substantial threat to our constitutional system of cooperative federalism":44

Suits involving traffic accidents occurring outside of Nevada could hardly interfere with Nevada's capacity to fulfill its own sovereign

nation despite the provision in article IIl for suits between a state and foreign states. Id. at 322-30.

36. 440 U.S. at $420-21$.

37. Id. at $421-24$.

38. Id. at 422-24. The Court relied on Pacific Ins. Co. v. Industrial Accident Comm'n, 306 U.S. 493, 502-03 (1939). The Supreme Court has simce applied this principle in Allstate Ins. Co. v. Hague, 101 S. Ct. 633, 637-40 (1981).

39. 440 U.S. at 424.

40. Id. at 424-25.

41. Id.

42. Id. at 426-27.

43. Id. at 425 .

44. Id. at 424 n.24. 
responsibilities. We have no occasion, in this case, to consider whether different state policies, either of California or of Nevada, might require a different analysis or a different result. 45

This footnote provoked criticisin from dissenting Justices Blackmun and Rehnquist. Justice Blackmun found a constitutional basis for interstate immunity in the concept of federalisin. ${ }^{46}$ Interstate immunity, he stated, was not inentioned in the Constitution because "it was too obvious to deserve mention." 47 Because the inajority had concluded that there was no constitutional basis for interstate immunity, Justice Blackmun did not understand how the Court could reach a different result in a non-traffic-accident case. ${ }^{48}$

In a separate dissent Justice Rehnquist asserted that interstate immunity was a necessary postulate "to make the Constitution a workable governing charter and to give each provision within that docunient the full effect intended by the Framers." 49 As evidence of this postulate Justice Rehnquist pointed out that the states ratifying the eleventh amendment, which closed the doors of the federal courts to most suits against states, must have assuned that they would enjoy immunity froin suit in the courts of sister states. ${ }^{50}$ Justice Rehnquist also noted that the same assunuption appears in repeated dicta in Supreme Court cases; 51 inoreover, it comports with the theory of Supreme Court cases that find states immune froin suit in the federal courts.52 Fimally, in view of the inajority's rejection of a constitutional foundation for imterstate immunity, Justice Rehnquist disparaged the suggestion that "cooperative federalism" may place limits on state court jurisdiction over another state.53 Should the Court attenpt to fashion such limits, he argued, it would be operating without principled guidance. ${ }^{54}$

45. $I d$.

46. Id. at 430-31 (Blackmun, J., joined by Burger, C.J., and Rehnquist, J., dissenting). Justice Blackmun noted, id. at 430 , that the Court had inferred constitutional rights from the structure of the Constitution im cases such as Shapiro v. Thompson, 394 U.S. 618 (1969) (right to travel).

47. 440 U.S. at 431.

48. Id. at 429.

49. Id. at 433 (Rehnquist, J., joined by Burger, C.J., dissenting). Justice Rehnquist analogized this postulate, $i d$. at $433-34$, to the immunity of federal instrumentalities from state taxes recognized in McCulloch v. Maryland, 17 U.S. (4 Wheat) 316 (1819) (holding that Maryland could not tax the Bank of the United States).

50. 440 U.S. at 437.

51. Id. at 438-39 (citing Western Umion Tel. Co. v. Pennsylvania, 368 U.S. 71 (1961), and Great N. Ins. Co. v. Read, 322 U.S. 47 (1944)).

52. 440 U.S. at 439-41 (citing Monaco v. Mississippi, 292 U.S. 313 (1934), and Hans v. Louisiana, 134 U.S. 1 (1890)).

53. 440 U.S. at 442-43.

54. Id. at 443. 


\section{The Sources of State Sovereign Immunity}

\section{A. Theoretical Bases for State Immunity.}

Both the Nevada v. Hall majority and the dissents limited their discussions of possible bases-for interstate immunity to constitutional sources. 55 This focus may have resulted in part from the Court's familiarity with the problems of state sovereign immunity in federal courtproblems that turn on the interpretation of the eleventh amendment and the impact of article III on common-law sovereign immunity. ${ }^{56}$ The majority appropriately distinguished the cases dealing with federal-court jurisdiction over states from the issue of imterstate immunity raised by the Nevada $v$. Hall facts. The dissents, in contrast, blurred the distinctions between the two types of immunity and rehed on the federal-court jurisdiction cases to argue that the Constitution preserved state immunity in the courts of other states. A closer look at the theoretical bases asserted for state immunity in the federal courts supports the majority's distimction.

Justice Marshall recently argued in Employees of the Department of Public Health and Welfare v. Missouri Department of Public Health and Welfare, ${ }^{57}$ that sovereigu immunity is purely a state common-law doctrine, removable by federal legislation within the article I powers of Congress. Article III, as clarified by the eleventh amendment, in contrast, limits federal judicial power over suits brought by an individual against a state without the state's consent. ${ }^{58}$ This theory permits suits on federal claims against states in state courts, ${ }^{59}$ but prevents Congress from subjecting the states to suit by individuals in federal court, because Congress cannot expand the constitutional limits of federal judi-

55. The Court stated that "No one claims that any federal statute places any relevant restriction on California's jurisdiction or lends any support to Nevada's claim of immunity. If there is a federal rule that restricts California's exercise of jurisdiction in this case, that restriction must be a part of the United States Constitution." Id. at 414 n.5.

56. See notes 33-35 supra.

57. 411 U.S. 279, 288, 297-98 (1973) (Marshall, J., concurring). In Employees the Court, in an opinion by Justice Douglas, held that Congress had not lifted the states' sovereign immunity, at least in federal court, when it extended the Fair Labor Standards Act, 29 U.S.C. \$\& 201-219 (1976), to state enuployees. See 411 U.S. at 285-86. Justice Marshall disagreed with the nuajority opinion on Congress's intent to abrogate the state's immunity, but concurred in the result on the ground that article III and the eleventh amendment precluded federal jurisdiction over damages suits brought by citizens against states. Id. at 290-92 (Marshall, J., concurring). Justice Brennan dissented, arguing that the states in ratifying the Constitution waived their sovereign immunity under congressional enactments that regulate state activity. Id. at 316-19 (Brennan, J., dissenting).

58. 411 U.S. at 291-92 (Marshall, J., concurring).

59. Id. at 297-98 (Marshall, J., concurring). The Suprenie Court has recently indicated that the eleventh amendment has no bearing on federally created causes of action brought in the state courts. Maine v. Thiboutot, 448 U.S. 1, 9 n.7 (1980). See also Maher v. Gagne, 448 U.S. 122, 130 n.12 (1980). 
cial power. Justice Marshall has accepted, however, the theory that a state may consent to suit in federal court by voluntary waiver of its immunity. ${ }^{60}$ The problem with Justice Marshall's analysis is that parties cannot by their consent confer subject-matter jurisdiction on the federal courts. ${ }^{61}$ Although an exception for state immunity may be historically justifiable, it is not logically justifiable.

Justice Brennan's analysis in Employees avoided the difficulty of Justice Marshall's theory. Justice Brennan agreed with Justice Marshall that sovereign immunity is purely a state common-law doctrine, and that the states gave Congress the power to remove that immunity. But Justice Brennan approached the eleventh amendment question differently, arguing that the amendment should be read literally to preclude only actions against states by citizens of other states or foreign states. Moreover, Justice Brennan, unlike Justice Marshall, read the eleventh amendment as an absolute bar to federal-court jurisdiction. ${ }^{62}$ Under Justice Brennan's theory, therefore, a state must answer to its own citizens in federal court if Congress so provides, but citizens of other states are relegated to state courts to press their federal claims. Justice Brennan's theory thus emphasizes the citizenship of the plaimtiff in determining whether a state may assert sovereign immunity. This result is difficult to reconcile with Hans $v$. Louisiana, ${ }^{63}$ which seems to reject such distinctions. ${ }^{64}$

A third theory, supported by Monaco v. Mississippi ${ }^{65}$ finds the states in most cases to be immune in federal court because the immunity is "inherent in the constitutional plan."66 Monaco v..Mississippi held that states are immune from suits brought by foreign nations, distinguishing this immunity (as well as the states' immunity from both citizens' and noncitizens' suits) from the amenability of states to suit by other states or the federal government on the theory that in the foriner cases, unlike the latter, the plan of the Constitution did not involve the

60. This was the theory of Parden v. Terminal Ry., 377 U.S. 184 (1964), see note 14 supra, which case Justice Marshall found to approach "the outer limit of the sort of voluntary choice which we generally associate with the concept of eonstitutional waiver." Employees v. Missouri Dep't of Pub. Health \& Welfare, 411 U.S. at 296 (Marshall, J., concurring).

61. See 411 U.S. at 321-22 (Brennan, J., dissenting). But see id. at 294 n.10 (Marshall, J., concurring).

62. Id. at 309-24 (Brennan, J., dissenting).

63. 134 U.S. 1 (1890).

64. See note 34 supra. Justice Brennan argued that Hans was based on the common-law principle of sovereign immunity and not on the Constitution. 411 U.S. at 311-14 (Brennan, J., dissenting).

65. 292 U.S. 313 (1934).

66. This is the theory that Justice Rehnquist in his Hall dissent sought to extend from state immunity in federal court to interstate immunity. See text accompanying notes 49-54 supra. 
surrender of immunity. ${ }^{67}$ This theory is consistent with Hans v. Louisiana in basing the states' retention of sovereign immunity on the Constitution as a whole rather than mooring it solely to the eleventh amendment. Moreover, the notion that sovereign immunity resides in the states unless the plan of the Constitution calls for its removal can be reconciled with cases upholding federal statutes that expose states to suits by individuals. ${ }^{68}$ Such statutes do not expand federal-court jurisdiction contrary to article III; rather, the constitutional plan calls for congressional power to curtail an otherwise secure immunity.

Professor Martha Field has criticized the idea that the Constitution, found by the Chisholm Court to abohish state immunity in federal court, should be interpreted to require such immunity (absent congressional action). ${ }^{69}$ Professor Field argues that a more logical position is that although article III, as clarified by the eleventh amendment, may not be interpreted to remove common-law state immunity, neither does that article require such immunity. ${ }^{70}$ This theory also can explain the Court's approval of federal statutes that exphicitly remove state immunity. Recent cases considering such statutes have involved the exercise of congressional power under the fourteenth amendment, ${ }^{71}$ but the theory that article III and the eleventh amendment have been amended by the fourteenth amendment, thus allowing suits against states under statutes enforcing the fourteenth amendment, is not as satisfactory as Professor Field's theory. ${ }^{72}$ Also unsatisfactory is the older rationale that a state that participates in a federal program waives its constitutional immunity. ${ }^{73}$

Professors John Nowak and Laurence Tribe agree that the Constitution does not prevent Congress from removing state immunity im fed-

67. 292 U.S. at 329-30.

68. See Hutto v. Finney, 437 U.S. 678 (1978); Fitzpatrick v. Bitzer, 427 U.S. 445 (1976).

69. Field, supra note 33, at 522-36; Field, supra note 14, at 1261-80.

70. Field, supra note 33 , at 536-49.

71. Hutto v. Finney, 437 U.S. 678 (1978); Fitzpatrick v. Bitzer, 427 U.S. 445 (1976).

72. The theory does not explain cases, such as Parden v. Terminal Ry., 377 U.S. 184 (1964), that were rationalized on a waiver theory. Moreover, there is no reason to eonclude that the fourteenth amendment granted Congress powers with characteristics different from those of the powers granted by article I. Field, supra note 14, at 1228-31; $c f$. Nowak, The Scope of Congressional Power to Create Causes of Action Against State Governments and the History of the Eleventh and Fourteenth Amendments, 75 CoLUM. L. REv. 1413, 1453-68 (1975) (examining the question whether the eleventh amendment restricts the scope of federal jurisdiction over civil rights actions brought under the fourteenth amendment).

73. See, e.g., Parden v. Terminal Ry., 377 U.S. 184 (1964). But see Florida Dep't of Health v. Florida Nursing Home Ass'n, 49 U.S.L.W. 3641 (U.S. Mar. 2, 1981) (per curiam); Edelman v. Jordan, 415 U.S. 651 (1974). 
eral courts. ${ }^{74}$ They have also argued, however, that the Constitution does provide immunity from judicially created causes of action-that is, actions created directly under the Constitution or implied from a statute. This distimction is based on the states' greater control over Congress than over the federal judiciary; the argument thus emphasizes the relevance of separation-of-powers considerations in determining state immunity from federal jurisdiction. ${ }^{75}$

Despite the differences among these theories, they all share a concern with the Constitution's effect on state immunity in the federal courts, not on sovereigu immunity in courts of sister sovereigus. The Nevada v. Hall inajority was therefore correct not to consider these theories in its mquiry into imterstate immunity. ${ }^{76}$ Instead, the Court relied on a Supreine Court case on international sovereign immunity, The Schooner Exchange v. McFaddon, ${ }^{77}$ to determine that the law of the forum state controls the extent to which a state can assert immunity in the courts of another state. Although the Court's analysis does not withstand scrutimy, the reference to The Schooner Exchange does suggest that international law should form the basis for interstate immunity. To examine the Court's analysis, however, it is first necessary to compare more fully the differing policy bases for doinestic and international sovereign immunity. ${ }^{78}$

\section{B. Policy Bases of State Immunity.}

The Nevada v. Hall Court accepted Justice Holmes's rationale for domestic sovereign immunity: "[T] here can be no legal right as against the authority that makes the law on which the right depends."79 This rationale has been challenged as a tautology, ${ }^{80}$ and is at odds with a constitutional system in which the ultimate authority that makes the law is the people, not the legislature. ${ }^{81}$ The Constitution, which reflects the people's will, curbs legislative action through judicial review; it is therefore illogical to preclude suit against the government for the rea-

74. Nowak, supra note 72, at 1453-68; Tribe, Intergovernmental Immunities in Litigation, Taxation, and Regulation: Separation of Powers Issues in Controversies about Federalism, 89 HARv. L. REv. 682, 683-99 (1976).

75. Nowak, supra note 72, at 1441; Tribe, supra note 74, at 694-95. The Nowak, Tribe, and Field theories are discussed in Comment, The Denial of Eleventh Amendment Immunity to Political Subdivisions of the States: An Unjustified Strain on Federalism, 1979 DUKE L.J. 1042, 1065-66.

76. 440 U.S. at $414-21$.

77. 11 U.S. (7 Cranch) 116 (1812).

78. The Court did look briefly at the purpose of domestic sovereign immunity but failed to contrast it with the purposes of intersovereign immunity. 440 U.S. at 416.

79. Id. at 416 (quoting Kawananakoa v. Polyblank, 205 U.S. 349, 353 (1907)).

80. C. JACOBS, supra note 33, at 155.

81. Id. See also Palmer, Hobbes, Holmes and Hitler, 31 A.B.A.J. 569 (1945). 
son given by Justice Holmes-that the government makes the lawbecause the government ultimately is subject to the law.

On the other hand, if the doctrine of domestic sovereign immunity is limited to actions for money damages-as for practical purposes it is, in the federal courts at least ${ }^{82}$ - then the "law" involved is the law providing for the payment of money out of the public fisc. When talking solely about the allocation of public funds, it is not incompatible with the American constitutional scheme to say that the legislature is "the authority that makes the law." The Court has never required Congress to legislate for the payment of damages nor overturned refusals of Congress to authorize such payment. Of course it may be said that this restraint follows from the sovereign immunity doctrine itself; thus we return to the initial criticism of the Holmes rationale - that it is circular.

From the volunie and vehemence of the criticism of domestic sovereign immunity, one might doubt that there is an articulable policy in its favor. ${ }^{83}$ The ability of legislatures to waive sovereign immunity and place conditions on that waiver, and the mability of courts to do so, suggest, however, that the purpose of domestic sovereign immunity is to preserve the separation of powers. The argument in favor of sucli an immunity is as follows.

To protect constitutional rights the courts can require governments to modify their actions in spite of the legislature's desires, because the courts have a superior ability, through imdependence and training, to be objective and to determine the nature of constitutional rights. Deciding whether or not to compensate persons for past violations depends, however, not on the definition of a right but on low public funds, which cannot provide for every good and proper cause, should be spent. This kind of decision is best made legislatively because of the

82. See Ex parte Young, 209 U.S. 123 (1908). For a review of the cases leading to Ex parte Young, see C. JACOBS, supra note 33, at 106-49. See also D. CURRIE, supra note 33, at 617-28. For more recent cases defining what rehef is available against a state official, see Quern v. Jordan, 440 U.S. 332 (1979); Edelman v. Jordan, 415 U.S. 651 (1974).

When Congress abolished the defense of sovereign immunity in Administrative Procedure Act suits against the federal government, it expressly applied the abolition to actions "seeking relief other than money damages." Act of Oct. 21, 1976, Pub. L. No. 94-574, 90 Stat. 2721 (amending 5 U.S.C. $\$ 702$ (1970)). The legislative history of the Act strongly suggests that the abolition of immunity in suits seeking relief other than money damages was an effort more to clarify than to change existing law. See S. REP. No. 996, 94th Cong., 2d Sess. 7 (1976); H.R. REP. No. 1656, 94th Cong., 2d Sess. 8, reprinted in [1976] U.S. CoDE CoNG. \& AD. NEws 6121, 6128. See generally S. REP. No. 996, 94th Cong., 2d Sess. 3-9, $25-26$ (1976); H.R. REP. No. 1656, 94th Cong., $2 d$ Sess. 4-10, 26, reprinted in [1976] U.S. CoDE CoNG. \& AD. News 6121, 6124-30, 6145-46 (letter froin the Attorney General).

83. See, eg., K. Davis, Administrative Law Treatise \$ 27.01, at 545-48 (1958); 2 F. HARPER \& F. JAMES, THE LAW OF TORTS $\$ 29.3$, at 1610-13 (1956). 
legislature's superior ability to allocate public funds, through its responsiveness to popular views and its ability to weigh interests. When statutory rights are involved, it follows a fortiori that coinpensation should be at the discretion of the legislature.

That the federal government and inany states have waived sovereign immumity strengthens rather than weakens the argument. It shows that legislatures do coinpare the public benefit of coinpensating victims of government torts and contract breaches to the benefit of other uses of public funds. And even when states waive sovereign immumity, the doctrine permits the legislature to limit recoveries for sound policy reasons. One example is the discretionary function exception ${ }^{84}$ to the Federal Tort Claims Act, ${ }^{85}$ which keeps litigants froin cliallenging the legality of government policy decisions through tort suits ${ }^{86}$ rather than through the Administrative Procedure Act. ${ }^{87}$ A second example is a dollar limit on the amount of recovery, like the limit in the Nevada statute considered in Nevada v. Hall, 88 which prevents the allocation of extraordinary amounts of public funds without independent legislative consideration. A third example is the preclusion of jury trials, ${ }^{89}$ which seeks to avoid the excessive verdicts that may result froin a jury's awareness of the government's deep pocket. In the federal courts, barring jury trials in civil actions against the United States is consistent with the seventh amendment ${ }^{90}$ because the doctrine of sovereign immumity permits the government to require trial to the court as a condition of waiver. ${ }^{91}$

The above argument grounds doinestic sovereign immumity in the separation between legislative and judicial functions. The argument for state immunity in the federal courts adds to these separation-ofpowers concerns the problem of allocating power between the federal government and the states. One's assessment of the relative competence of the federal legislature, the federal courts, and the state legislatures to make compensation decisions depends largely on one's view of the degree to which states should be independent of the federal government.

84. 28 U.S.C. § 2680 (a) (1970).

85. Id. $\S 82671-2680$.

86. See Dalehite v. United States, 346 U.S. 15 (1953).

87. 5 U.S.C. $\S \S 553-558$ (1976).

88. 440 U.S. 410,412 n.2 (1979).

89. See, e.g., 28 U.S.C. $\$ 2402$ (1976) (forbidding jury trials in cases brought against the United States under 28 U.S.C. $\$ 1346$ (1976), except for optional jury trials under section $1346(a)(1))$.

90. U.S. CoNST. amend. VII.

91. Lehman v. Nakshian, 49 U.S.L.W. 4835, 4836 (U.S. June 26, 1981); Glidden Co. v. Zdanok, 370 U.S. 530, 572 (1962) (plurality opinion); United States v. Sherwood, 312 U.S. 584, 587 (1941); McElrath v. United States, 102 U.S. 426, 440 (1880). 
Intersovereign immunity has traditionally been based on different policy considerations. The question is no longer which part of a single government shall allocate public funds. Instead, the question is whether the judicial arm of one government should have authority to resolve disputes involving another equal government without that government's consent. The argunent in favor of intersovereign immunity is as follows.

A state perceives its being brought before the courts of a legally equal state as an affront to its dignity. ${ }^{92}$ Such perceived indignities nay burden the friendly relations of the two states. A court order of one government to seize the property of another government in order to enforce a judgment presents even greater dangers of hostility. ${ }^{93}$ To preserve friendly and peaceful relations between sovereigns, disputes should be resolved by negotiation or by reference to a higher authority. In the international sphere an individual's claim against a foreign government nay be presented diplomatically by his government. ${ }^{94}$ This inethod both preserves peace and confines dealings with foreign states to the executive branch, which is nore capable and flexible in international affairs than the judicial brancli. ${ }^{95}$

Thus, the justifications for intersovereign immunity do, as the $\mathrm{Ne}$ vada $v$. Hall majority suggested, differ froin those for doinestic sovereign immunity. Dolnestic sovereign immunity involves the separation of powers in the allocation of funds; intersovereign immunity involves the peaceful relations of equal nations or states. Accordingly, the authorities one examines to determine the source of doinestic sovereign immunity are of little use in determining the source of intersovereign immunity. Justice Stevens's majority opinion in Nevada v. Hall looked to international law to uncover the source of intersovereign immunity. This inquiry led him to the case of The Schooner Exchange v. McFaddon, ${ }^{96}$ the principal authority for intersovereign immunity in the international context.

92. See, e.g., French Republic v. Board of Supervisors, 200 Ky. 18, 22, 252 S.W. 124, 125 (1923); The Parlement Belge, 5 P.D. 197, 207, 214, 220 (C.A. 1880).

93. See United States and France v. Dollfus Mieg et Cie. S.A. and Bank of England, [1952] A.C. 582, 605; The Arantzazu Mendi, [1939] A.C. 256, 265.

94. See Aldona S. v. United Kingdom, 90 Journal du Droit International 190 (Pol. Sup. Ct. 1948) (1963).

95. The French courts are reported to have relied particularly on this rationale. Lauterpacht, The Problem of Jurisdictional Immunities of Foreign States, 28 BRIT. Y.B. INT'L L. 220, 234 (1951).

96. 11 U.S. (7 Cranch) 116 (1812). 


\section{The Misapplication of THE SCHOONER EXCHANGE}

In The Schooner Exchange v. McFaddon ${ }^{97}$ American citizens libeled a French naval vessel in American waters, alleging that the Frencli had wrongfully taken the vessel the year before. The Supreine Court, in an opinion by Chief Justice Marshall, held that a public armed vessel of a foreign sovereign at peace with the United States was immune frow the jurisdiction of United States courts. ${ }^{98}$ Language in the Chief Justice's opinion led the Nevada $v$. Hall majority to conclude that "if California and Nevada were independent and conıpletely sovereign nations, Nevada's claim of immunity from suit in California's courts would be answered by reference to the law of California."99 Such a conclusion is unwarranted; indeed it suggests the absence of any binding international law.

Chief Justice Marshall, in his analysis of the Frencli claim of in1munity, first pointed out that "The jurisdiction of courts is a brancl of that which is possessed by the nation as an independent sovereign power."100 In other words, courts set up by a government derive their authority from the same source as does that government, and may not, either practically or theoretically, rule in contradiction of that source of authority. ${ }^{101}$ In the United States this means, of course, that the courts must rule consistently with the Constitution and with valid laws passed under the authority of that Constitution, even if some other source of authority such as international law requires a different result. Thus the federal courts, as domestic courts, must prefer federal statutes to inconsistent previous treaty obligations, ${ }^{102}$ or inconsistent custounary international law. ${ }^{103}$ As Judge Learned Hand said on behalf of the Court of

97. Id.

98. Id. at $145-46$.

99. 440 U.S. at 417.

100. 11 U.S. (7 Cranch) at 136, quoted in Nevada v. Hall, 440 U.S. at 416.

101. Chief Justice Taney put it this way:

Judicial power presupposes an established government capable of enacting laws and enforcing their execution, and of appoimting judges to expound and administer them. The acceptance of the judicial office is a recognition of the authority of the government from which it is derived. If [a state court] decides at all as a court, it necessarily affirms the existence and authority of the government under which it is exercising judicial power.

Luther v. Borden, 48 U.S. (7 How.) 1, 40 (1849). See also Adams v. Adams, [1970] 3 All E.R. 572, 591-92; R. v. Ndhlovu, [1968] S. Afr. L.R. 515, 520-23, 535, 543 (High Court of Rhodesia).

102. See, e.g., The Chinese Exclusion Case, 130 U.S. 581, 600-03 (1889) (upholding a Chinese exclusion law violating an earlier treaty); Diggs v. Schultz, 470 F.2d 461, $465-67$ (D.C. Cir. 1972) (Congress may legislate in breach of United Nations Charter obligations).

103. See The Over the Top, 5 F.2d 838, 842 (D. Conn. 1925). Similar rules are applied in the courts of other nations. See, e.g., Croft v. Dunphy, [1933] A.C. 156, 164; Pohtes v. Australia, 70 C.L.R. 60 (Aust1. 1945); Attorney-General v. Eichunann, 36 I.L.R. 277, 280 (Sup. Ct., Israel, sitting as Ct. Crim. App. 1962). 
Appeals for the Second Circuit, "[A]s a court of the United States, we cannot look beyond our own law."104 Federal courts apply international law only to the degree that it is "part of" the law of the United States. ${ }^{105}$ In soine countries, to be sure, constitutions require that international law be applied over subsequently enacted doinestic laws, but even in such cases it is because the constitution in question incorporates international $1 \mathrm{aw}^{106}$ that the donnestic court applies it. Thus it is almost a truism that courts apply the law of the authority fron which they draw their power.

Chief Justice Marshall then observed that any limit on the authority of a sovereign and independent nation must derive ultimately froin the consent of the nation. ${ }^{107}$ This does not inean, of course, that a nation cannot bimd itself internationally. If so, there would be no such thing as international law. ${ }^{108}$ Instead it means that the ultimate source of imternational law, which is fonnd primarily in treaties and custom, ${ }^{109}$ is the consent of nations. Treaties are plainly the product of consent; the same can be said of customary international law, smce custont is bimding because (and only if) it refiects what states deem to be required by law. ${ }^{110}$

104. United States v. Aluminum Co. of America, 148 F.2d 416, 443 (2d Cir. 1945).

105. The Paquete Habana, 175 U.S. 677, 700 (1900). See also Triquet v. Bath, 3 Burr. 1478, 1481, 97 Eng. Rep. 936, 938 (K.B. 1764).

106. E.g., CostituzIONE art. 10 (Italy) and GRUNDGESETZ art. 25, III (W. Ger.), reprinted in A. Peaslee, Constitutions of Nations 501 \& 366 (3d ed. 1968).

107. The jurisdiction of the nation, within its own territory, is necessarily exclusive and absolute; it is susceptible of no limitation, not imposed by itself. Any restriction upon it, deriving validity from an external source, would imply a diminution of its sovereignty, to the extent of the restriction, and an investment of that sovereignty, to the same extent, in that power which could impose such restriction. All exceptious, therefore, to the full and complete power of a nation, within its own territories, must be traced up to the consent of the nation itself. They can flow from no other legitimate source.

11 U.S. (7 Cranch) at 136, quoted in Nevada v. Hall, 440 U.S. at 416.

108. See A. D'Amato, The Concept of Custom in International Law 189-90 (1971).

109. The Statute of the International Court of Justice recites that the court will apply, in addition to treaty and custon, "general principles of law recognized by civilized nations." I.C.J. STAT. art. 38, I 1(c), June 26, 1945, 59 Stat. 1055, T.S. No. 993. This authorization to analogize to the domestic law applied generally in civilized nations may have been an expansion of previously recognized sources of international law, and in any event it has not become a major legal resource for international legal decisionmakers. See M. Hudson, The Permanent Court of InTERnaTIONAL JUSTICE, 1920-1942 610-12 (1943). Other sources of international law such as judicial decisions and teachings of publicists, are subsidiary means for determining what treaties, custom, and general principles require. I.C.J. STAT. art. 38, \ 1(d); see M. HUDSON, supra, at 612-15.

110. The Lotus, [1927] P.C.I.J., ser. A, No. 9, at 18; see M. AKEHURST, A MODERn INTROdUCTION to INTERnational LAW 35-39 (3d ed. 1977); J. BRIERLEY, The LAW OF NATIONS 59-62 (5th ed. 1963); H. LAUTERPACHT, OPPENHEIM'S INTERNATIONAL LAW 25-27 (8th ed. 1955); Fitzmaurice, The Law and Procedure of the International Court of Justice, 1951-54: General Principles and Sources of Law, 30 BRTT. Y.B. INT'L L. 1, 68 (1953); MacGibbon, Customary International Law and Acquiescence, 33 BRrT. Y.B. INT'L L. 115, 144-45 (1957). The International Court of Justice 
There are several reasons why these two points were necessary to Marshall's decision that the French warship was protected by sovereign immunity. First, regardless of what international law required, if American law was to the contrary, then Marshall could not find immumity, because the Supreme Court is a court of the Uinted States. Second, international law would not require immunity if the United States did not consent in some sense to that requirement. There is such consent, however, if international custom reflects a general practice accepted as law. In the next portion of The Schooner Exchange, not quoted by the Nevada v. Hall majority, the Court discussed this point: "This consent may be either express or imphed. In the latter case, it is less determinate, exposed more to the uncertainties of construction; but, if understood, not less obligatory." 111 Chief Justice Marshall then demonstrated that international custorn required immunity in the circumstances, 112 and concluded that the immunity constituted "a principle of public law."113 Thus The Schooner Exchange found the United States bound as a nation on the international plane to respect the immunity of the vessel.114 The opinion went on expressly to note that if the United States required the Court to violate that obligation, the

applies custom "as evidence of a general practice accepted as law." I.C.J. STAT. art. 38, I 1(b), June 26, 1945, 59 Stat. 1055, T.S. No. 993.

111. 11 U.S. (7 Cranch) at 136-37. Chief Justice Marslall continued:

This consent may, in some instances, be tested by common usage, and by common opinion, growing out of that usage.

A nation would justly be considered as violating its faith, although that faith might not be expressly plighted, which should suddenly and without previous notice, exercise its territorial powers in a manner not consonant to the usages and received obligatious of the civilized world.

Id.

112. See id. at 137-45.

113. Id. at 145 .

114. The English courts have so interpreted Chief Justice Marshall's opinion, see The Cristina, [1938] A.C. 485, 508-09, and, apart from the issue of the extent to which the doctrine is to be applied, authorities on international law generally agree that sovereign immunity is required as a matter of international law and is not discretionary with the forum state. Id. at 502; Pauer v. Hungarian People's Republic, [1957] I.L.R. 211, 212 (Corte cass., Italy, 1956). See also M. AKehurst, supra note 110, at 109; I. Brownlie, Principles of PUblic International LaW 333 (3d ed. 1979); 2 D. O'Connel., InTERnational Law 843 (2d ed. 1970); Deák, Organs of States in their External Relations: Immunities and Privileges of State Organs and of the State, im Manual of Public International Law 425 (Sorenson ed. 1968); Letter from Jack B. Tate, Acting Legal Adviser, to Department of Justice (May 19, 1952), reprinted in 26 Dep'T STATE BULl. 984 (1952); Restatement (SECOND) OF Foreign Relations Law of the UNited States $\S 63$, Comment a to $\$ \S 63,65$ (1965). But see Lauterpacht, supra note 95, at 228-29. In passing the Foreign Sovereign Immunities Act of 1976, Pub. L. No. 94-583, 90 Stat. 2891 (1976) (codified at 28 U.S.C. $\S \S 1330,1602-1611$ (1976)), Congress made clear that it was attempting to conform the legislation to the requirements of international law. See H.R. REP. No. 1487, 94th Cong., 2d Sess. 7, 8, 22, 23, reprinted in [1976] U.S. CODE CoNG. \& AD. News 6604, 6604-06, 6621-22. 
Court, as a domestic court, would do so, but such was not the case. ${ }^{115}$

The Nevada v. Hall Court read The Schooner Exchange to support the proposition that if California and Nevada were imdependent and completely sovereign nations, then Nevada's assertion of immunity in California courts would depend solely on California law. ${ }^{116}$ The Court thus analogized Nevada's claim of immunity in California courts to France's claim of immunity in United States courts. The analogy does not hold, however, because California and Nevada courts are unlike those of the United States in The Schooner Exchange in one important respect: California courts are not truly donnestic courts of California in the same sense that the United States Supreme Court is a domestic court of the United States. This is because the decisions of California's high court are appealable to a court that can require California to conforn to interstate rules: the United States Supreme Court.

If appeal lies froin one court to the court of a higher authority, the first court must apply not only the law of the authority that gives the court power, but also the law of the higher authority. Since Martin $v$. Hunter's Lessee 117 it has been clear that the Uinited States Supreme Court can constitutionally reverse final state-court decisions affecting federal rights. The Constitution makes federal law supreme, ${ }^{118}$ but it is the inechanism of review that compels a state court to apply federal law rather than state law when the two conflict. ${ }^{119}$ Supreine Court review makes courts of the states also in a sense courts "of the United States." If decisions of the Supreme Court of the United States were appealable to a world court, let us say, in the Hague, then the Supreine Court would be unable to apply United States law that was in conflict with international obligations. Just as the Constitution makes federal law superior to state law, international law is superior (in theory) to national law. ${ }^{120}$ If the Hague World Court could reverse the judgments of the Supreme Court, the Supreme Court would become a lower court of the international system. International law would then prevail over mconsistent United States law, and the principle of applying interna-

115. 11 U.S. (7 Cranch) at 146.

116. 440 U.S. at 417.

117. 14 U.S. (1 Wheat.) 304 (1816).

118. U.S. CoNST. art. VI.

119. For this reason states' rights advocates have historically challenged Supreme Court review of state decisions. See generally P. Bator, P. Mishkin \& H. WeChSLer, HaRT \& WeChSLER'S THE FeDERAL COURTS AND THE Federal SYSTEM 442-60 (2d ed. 1973) [hereinafter cited as HART \& WECHSLER].

120. Restatement (Second) of Foreign Relations Law of the United States \& 3(2) (1965); see M. Hudson, supra note 109, at 614-15; Vienna Conv. on the Law of Treaties art. 46, U.N. Doc. A/CONF. 39/27 (1969). 
tional law only to the extent that it is "part of" domestic law would collapse.

This very phenomenon has occurred in Western Europe. The treaties establishing the European Economic Community ${ }^{121}$ create extensive international rights and duties among the members. ${ }^{122}$ Under traditional analysis a court of one of the member states could not enforce such obligations in contravention of a constitutional law of that state. But there are treaty provisions creating a higher court, the Court of Justice of the European Communities, which effectively reviews decisions of national courts on the interpretation of European Community law. ${ }^{123}$ In the face of several challenges, the European Court has consistently required domestic courts to apply Community law despite the internal law of the member states, even if that imternal law is of constitutional dimensions. ${ }^{124}$ On Community law issues, then, the domestic courts have in a real sense become courts "of the Community" rather than courts of, for instance, Italy or the Netherlands.

But the Supreme Court is not subordinate to any international tribunal, and was not subordimate in 1811 when The Schooner Exchange was decided. Chief Justice Marshall was correct, therefore, in first finding sovereign immunity to be a part of the law of the United States before applying it in a court of the United States. Marshall's analysis does not imply, however, what the majority im Nevada v. Hall inferred: that sovereign immunity would not be binding internationally even if United States law were to the contrary. Under Marshall's analysis if United States law conflicted with an international rule, the Supreme Court, as a court of the United States not subject to review, would apply domestic law im violation of international law. A state court, im contrast, is subject to review by a higher authority; the Supreme Court in fact exercised that authority in the Nevada $v$. Hall case itself. Thus a state court, unlike a domestic court not subject to review, must bring its law into conformity with a relevant higher law. The Schooner Ex-

121. The Treaty Establishing the European Economic Community, 298 U.N.T.S. 11, art. 189, mandates that Community "regulations," a form of legislation enacted by Community institutions, are "directly applicable" law.

122. See generally E. Stein, P. HAY \& M. WAELBRoEck, European CoMMUNitY LAW AND Institutions In Perspective (1976); R. Wortley, The LAW of the Common MaRKet (1974).

123. The Treaty Establishing the European Economic Community, 298 U.N.T.S. 11, art. 177.

124. Administrazione delle Finanze dello Stato v. Simmenthal, [1978] E. Comm. Ct. J. Rep. 629, 23 Comm. Mkt. L.R. 263; Costa v. ENEL, [1964] E. Comm. Ct. J. Rep. 585, [1964] Comm. Mkt. L.R. 425; see Salimbene, National Sovereignty: Britain Against the European Court, 3 SuFFOLK Transnat'l L. REv. 185 (1979); Stein, Lawyers, Judges and the Making of a Transnational Constitution, 75 AM. J. INT'L L. 1 (1981); Stein, Treaty-Based Federalism, A.D. 1979: A Gloss on Covey T. Oliver al The Hagne Academy, 127 U. PA. L. REv. 897, 900-08 (1979); Note, The Primacy of European Community Law, 15 TEx. INT'L L.J. 139 (1980). 
change accordingly provides no basis for the majority's conclusion in Nevada $v$. Hall that interstate immunity exists only if found in the law of the forum state. 125

\section{The Application of International LAW to INTERState IMMUNITY}

Of course an immunity may be applied in the higher forum only if there is a basis for it. The Nevada v. Hall opinion can be read to indicate that the full faith and credit clause might require interstate immunity in an appropriate case, altliough it held that state law controlled the case at bar. ${ }^{126}$ But the Court should liave looked to international law as the law that governs relations between the states, when not displaced by the Constitution or by federal statute. Although the Court inisconstrued The Schooner Exchange, the application of international law to relations between the states is sound and sliould govern the extent to which states possess immunity fronl suit in each other's courts.

In exercising its original jurisdiction over disputes between states, ${ }^{127}$ the Supreme Court has often applied principles of international law in the absence of applicable constitutional or federal statutory provisions. ${ }^{128}$ The nrost frequent exainple has been in resolving river boundary disputes. ${ }^{129}$ Nothing in the Constitution speaks of accretion, avulsion, or the thalweg of a river, nor does the schenie of the Constitution indicate how such concepts should be applied. Nonetle-

125. Moreover, there is no indication in The Schooner Exchange that deference to United States law is required on the particular international law issue of immunity. Marshall's discussion of United States consent relates only to a determination of whether there is a prior binding coinmitment under international law.

126. See text accompanying note 45 supra. One might argue that the full-faith-and-creditclause doctrine can define the circumstances under which "cooperative federalisn" requires state sovereignty. Such an approach would, however, distort accepted principles that determine when the clause requires the application of the law of a nonforum state. See text accompanying note 38 supra. In essence, choice-of-law doctrines inherent in the full faith and credit clause are not appropriate for the resolution of immunity claims because the policy bases for rules of immunity, see notes 79-96 supra and accoinpanying text, are not the same as those supporting rules on which law to apply. See Stewart, supra note 3, at 264-78; The Supreme Court, 1978 Term, supra note 3, at $195-98$.

127. U.S. CoNST. art. III, $\S 2$ provides: "In all Cases . . . in whicl a State shall be Party, the supreme Court sliall have original Jurisdiction."

128. Note, The Original Jurisdiction of the United States Supreme Court, 11 STAN. L. REv. 665, 680-83 (1959); $c f$. H. SMITH, The AMERICAN Supreme Court as an INTERNATIonal Tribunal 41-43, 51, 83-84 (1920) (argument for interstate common law as the authority in disputes between States).

129. See, eg., Arkansas v. Tennessee, 310 U.S. 563, 570 (I940); Wisconsin v. Michigan, 295 U.S. 455, 461 (1935); New Jersey v. Delaware, 291 U.S. 361, 378-84 (1934) (exteusive use of international law sources); Michigan v. Wisconsin, 270 U.S. 295, 308 (1926); Louisiana v. Mississippi, 202 U.S. 1, 49-53 (1906). 
less the Supreine Court has applied international law in such cases. The Court has also applied international law to disputes between states over water rights ${ }^{130}$ and water pollution. ${ }^{131}$

The constitutional basis for the application of international law is the provision for federal jurisdiction over disputes between states and for original jurisdiction in the Supreine Court over disputes to which a state is a party. ${ }^{132}$ The theory is not only that the Supreme Court must apply some rule to resolve disputes between states, but also that the Constitution contemplates the Supreme Court as a substitute for diplomacy and war-methods that sovereign states use to enforce their rights under international law but that the states surrendered when they ratified the Constitution. ${ }^{133}$ The same analysis applies to any suit in which a state is a party. Article III of the Constitution extends the judicial power of the Umited States not only to controversies between two or more states, but also to controversies between a state and citizens of another state. ${ }^{134}$ Moreover, the origmal jurisdiction of the Supreme Court extends to both types of cases. ${ }^{135}$

Justice Holmes's analysis in Missouri v. Illinois ${ }^{136}$ supports the conclusion that the Supreme Court may apply international law in a suit between a state and the citizens of another state, as well as in a suit between states. In denying the right of Missouri to enjom Chicago's discharge of sewage into a river flowing into Missouri, the Supreme Court distinguished between a nuisance warranting an equity suit by one citizen against another, which would not trigger Supreme Court jurisdiction, and a nuisance that "might be created by a State upon a navigable river like the Danube, which would amount to a casus belli for a State lower down [the river] unless removed,"137 which would warrant an original Supreme Court suit. ${ }^{138}$ In arriving at this distimction, the Court reasoned:

130. See Connecticut v. Massachusetts, 282 U.S. 660, 670 (1931); Kansas v. Colorado, 185 U.S. 125, 146-47 (1902).

131. See Missouri v. Illinois, 200 U.S. 496, 518-21 (1900) (suit to restrain discharge of sewage).

132. See note 127 supra and note 134 infra.

133. See Kansas v. Colorado, 185 U.S. 125, 140-42 (1902).

134. U.S. CoNST. art. III, $\$ 2$ provides: "The judicial Power shall extend . . . -to Controversies between two or more States; - between a State and Citizens of another State . . . "

135. See note 127 supra. The constitutional grant of original jurisdiction to the Supreme Court in cases in which a state is a party need not be exclusive. See HART \& WECHSLER, supra note 119, at 242-43. Congress has made jurisdiction over controversies between states exclusive in the Supreme Court, but has not made controversies between a citizen and a state exclusive. See 28 U.S.C. \& 1251 (Supp. II 1978).

136. 200 U.S. 496 (1906).

137. Id. at $520-21$.

138. The Court found that the harm in the case before it was not sufficiently shown to put the case in the latter category. Id. at 526 . 
In the case at bar. ... there is no suggestion that [Congress] has forbidden the action of Illinois. The only ground on which that State's conduct can be called in question is one which must be implied from the words of the Constitution. The Constitution extends the judicial power of the Uinted States to controversies between two or more States and between a State and citizens of another State, and gives this court original jurisdiction in cases in which a State sliall be a party. Therefore, if one State raises a controversy with another, this court must determine whether there is any principle of law and, if any, what, on whicl the plaintiff can recover. ${ }^{139}$

Just as the grant of judicial power is used as authority to apply international law to disputes between states in Missouri $v$. Illinois, the grant of judicial power over disputes between a state and citizens of another state, which Justice Holmes also inentioned, should be deeined as well to authorize the application of international law in an appropriate case.

There are two possible problems with the application by the Supreme Court of international law rights and duties in cases between a citizen and a state, as opposed to cases between states. First, there nay be eleventh amendment immunity in the former case, but not in the latter. Second, the statute providing for Supreme Court appellate jurisdiction for state cases arguably does not permit the application of international law as a basis for reversing a state court judgment.

Under article III of the Constitution as modified by the eleventh amendment, states are immune froin suit by individuals in federal court, but not immune from suit by other states. ${ }^{140}$ One might argue that the Supreme Court, being subject to article III and the eleventh amendment, lacks jurisdiction to hear a suit by an individual against a state, even on appeal from a state court: if a federal district court is constitutionally precluded from hearing such a suit, the Supreme Court is likewise precluded. The eleventh amendment and the portion of article III affected by it refer to the judicial power of the United States, and do not distimguish between lower courts and the Supreine Court. ${ }^{141}$

139. Id. at 519-20. The Court coutinued:

But the fact that this court must decide does not mean, of course, that it takes the place of a legislature. Some principles it must have power to declare. For instance, when a dispute arises about boundaries, this court must determine the line, and in doing so must be governed by rules explicitly or implicitly recognized. It must follow and apply those rules, even if legislation of one or both of the States seems to stand in the way.

Id. (citation omitted) (emphasis added). See also City of Milwaukee v. Illinois, 49 U.S.L.W. 4445, 4453-54 (U.S. April 28, 1981) (Blackmun, J., dissenting).

140. Compare Hans v. Louisiana, 134 U.S. 1 (1890), with Monaco v. Mississippi, 292 U.S. 313, 328-29 (1934).

141. The Supreme Court has decided that a case involving a federal issue does not "arise under . . . the Laws of the United States" for purposes of federal district court jurisdiction when the federal issue may be properly raised only as a defense, see Louisville \& Nashville R.R. v. Mottley, 211 U.S. 149 (1908), but the Supreme Court nuay decide the same issue on review of a 
This argument is, lowever, implicitly rejected in Nevada v. Hall itself. If the Court had no jurisdiction to hear the state's petition because of limitations on the federal judicial power, it should lave dismissed the case for lack of jurisdiction, regardless of whether, on the merits, the Constitution required the state to apply immunity. ${ }^{142}$ By examining the merits the Court clearly exercised its jurisdiction. Moreover, not to have heard the case because of the eleventh amendment would liave produced an anomaly: the very constitutional provisions that ensure the immunity of states in federal courts would preclude the federal enforcement of immunity in state courts.

A better interpretation is that the article III grant of judicial power over controversies "between a State and Citizens of another State" was intended to give states a federal court forum, when appropriate, to assert any applicable immunity, whether from state or federal jurisdiction. This approacl is consistent with the idea that article III by its terms neither requires nor precludes domestic sovereign immunity. ${ }^{143}$ Indeed, it provides an explanation for the language's presence in article III in the first place. One argument against state immunity in federal courts, accepted in Chisholm v. Georgia, ${ }^{144}$ is that the extension of judicial power over controversies "between a State and Citizens of another State" could not logically be limited to suits in which the state is a plaintiff. This argument may be refuted by noting that when a state is a defendant, the federal court should have a limited jurisdiction to determine whether the state has an immunity. In effect, this liappens when any federal court takes jurisdiction to determine whether there is iminunity. There is no reason why the Supreme Court, in the exercise of its appellate jurisdiction, should not be able to determine whether iminunity exists. If the Supreme Court can do so, its authority inust come from the jurisdictional grant of article III over controversies "between a State and Citizens of another State." The Supreme Court, hearing a case on certiorari from a state court, is accordingly not precluded by

state court decision, see Louisville \& Nashville R.R. v. Mottley, 219 U.S. 467 (1911). According to Professor Charles Alan Wright, the only way to reconcile the two Mottley decisions is to reason that the first Mottley decision interpreted the statutory "arising under" language in the Judicial code more narrowly than the second Mottley decision interpreted the same language in article III. C. WRIGHT, LAw OF FEDERAL CourTs 69-70 (3d ed. 1976). Professor Wright's conclusion implies that the extent to which the first paragraph of article III, section 2, of the Constitution extends the judicial power of the United States does not depend on the level-district, appellate, or supreme - of federal court involved. See also Osborn v. United States, 22 U.S. (9 Wheat.) 738, 821 (1824).

142. In Hans v. Louisiana, 134 U.S. 1 (1890), for instance, the Supreme Court dismissed the coinplaint even though a constitutional issue was involved.

143. See text accompanying note 70 supra.

144. 2 U.S. (2 Dall) 419, 450-52, 467-68, 476-77 (1793). 
article III or the eleventh amendment from determining whether the state is immune from suit.

A more difficult problem is that although the Supreme Court may constitutionally decide on an appeal from state court whether the state is immune, Congress has arguably limited that appellate jurisdiction to cases in which the immunity is based on the Constitution. ${ }^{145}$ The Judicial Code provides for Supreme Court review of state high court decisions "where any title, right, privilege or immunity is specially set up or claimed under the Constitution, treaties or statutes of . . . the United States."146 There was hittle difficulty with the application of this provision in Nevada v. Hall, for Nevada asserted that its immunity was based on the Constitution and was, therefore, an "immunity ... claimed under the Constitution."147 If a state argues, however, that a quasi-sovereigu state has immunity as a matter of international law, and that nothing in the Constitution or federal law supersedes or removes that immunity, one might argue that the defendant has no "title, right, privilege or immunity . . . specially set up or claimed under the Constitution, treaties or statutes" and that Congress has accordingly withdrawn from the Court's appellate jurisdiction cases in which an international law immunity is asserted. This too would be an anomalous result, for the Supreme Court should be the final arbiter of all rights and duties superior to state law.

This anomaly does not result, however, because international rights and duties of states among themselves are in one sense constitutional. If one considers the Constitution to be the resolution of the totality of rights and duties of states among themselves, then the application of international law rights and duties by the Supreme Court is a recognition that the Constitution preserves those rights and duties. In that sense interstate sovereign immunity, to the extent it is recognized under international law and not limited by Constitution or statute, is an immunity "claimed under the Constitution." This theory is supported by Supreme Court decisions that refer to the application of

145. Article III grants the Supreme Court original jurisdiction without qualification. U.S. ConsT. art. III, § 2. While Congress cannot take away this jurisdiction, it can make it concurrent with lower federal courts. See HART \& WECHSLER, supra note 119, at 242-43. In contrast, the appellate jurisdiction of the Supreme Court is subject to "such Exceptions, and under such Regulations as the Congress shall make." U.S. CoNST. art. III, § 2; see Ex parte McCardle, 74 U.S. (7 Wall.) 506 (1869).

146. 28 U.S.C. \& 1257(3) (1976).

147. 440 U.S. at 414 . The plaintiffs in Nevada v. Hall argued without support that under section 1257(3) "a claim can only be made by citizens of the Umited States." Opposition to Petition for Certiorari at 2, 6-7, Nevada v. Hall, 440 U.S. 410 (1979); Brief for Respondents at 2, Nevada v. Hall, 440 U.S. 410 (1979). 
international law to interstate disputes as federal common law, ${ }^{148}$ and by analogy to admiralty law. Because the judicial power extends to controversies between states, controversies between a state and the citizens of another state, and cases of admiralty and maritime jurisdiction, the Court is forced in these contexts to determine law that does not depend on the law of mdividual states. ${ }^{149}$ Because the power to declare the law is derived from the grant of judicial power, ${ }^{150}$ the immunity is constitutional. Just as an issue of federal admiralty law would be subject to the appellate jurisdiction of the Supreme Court, ${ }^{151}$ even though the Constitution does not indicate how a particular admiralty issue should be decided, so an issue of intersovereign immunity would be subject to the Supreme Court's appellate jurisdiction, despite the absence of a requirement of immunity in the plan or language of the Constitution.

\section{The Requirements of INTERSOVEREIGN IMMUNITY}

Even if the Supreme Court should have applied principles of imternational sovereign immunity in Nevada $v$. Hall as federal common law, it came to the proper judgment. This is so because international sovereign immunity has been greatly limited in the twentieth century. ${ }^{152}$ The law has changed from absolute to restrictive sovereign immumity. ${ }^{153}$ Complete immunity of one nation in the courts of another has given way, generally but not universally, to immunity only when the state acts im a public rather than in a commercial capacity. This development has coimcided with the development of extensive governmental undertakings in the areas of industry and commerce, particularly in socialist states. ${ }^{154}$

148. See, e.g., Kansas v. Colorado, 206 U.S. 46, 98 (1907). See Note, supra note 128, at 682.

149. With respect to controversies involving states, see notes 127-39 supra and accompanying text. With respect to cases in admiralty, see Knickerbocker Ice Co. v. Stewart, 253 U.S. 149, 157. 58, 160-61 (1920); Southern Pac. Co. v. Jensen, 244 U.S. 205, 214-15 (1917).

150. See HART \& WECHSLER, supra note 119, at 786-87.

151. See Belden v. Chase, 150 U.S. 674,691 (1893).

152. That the law changes in part because of developinents outside of the United States should not prevent the Supreme Court from applying that law. In changing the law of divided damages in admiralty, for instance, the Court relied in part on the changes in admiralty law in the courts of other nations. See United States v. Reliable Transfer Co., 421 U.S. 397, 397-98, 403-04, 411 (1975).

153. Lauterpacht, supra note 95, at 250-72; Sucharitkul, Immunities of Foreign States Before National Authorities, 149 ACADEMIE DE DROIT INTERNATIONAL, RECUEIL DES COURS 87 (1976); von Mehren, The Foreign Sovereign Immunities Act of 1976, 17 CoLUM. J. TRANSNAT'L L. 33, 3643 (1978).

154. Von Mehren, supra note 153, at 36-37. 
The difficulty with restricting the immunity that had formerly been absolute was in drawing the line between public activities (acta jure imperii) and commercial activities (acta jure gestionis). ${ }^{155}$ Nonetheless, the United States State Department announced in 1952 that in the future it would apply the restrictive theory of sovereign immunity. ${ }^{156}$ Until 1976 the courts generally deferred to State Departinent decisions about the immunity of a foreign state. ${ }^{157}$ The Foreign Sovereign Iminunities Act of 1976, 158 however, gave the courts the task of determining when a foreign state is immune under the Act. ${ }^{159}$ The Act atteinpts to codify the current American view of international law, that is, the restrictive theory. ${ }^{160}$ It is thus the nost authoritative source for the Supreine Court to consider in applying international law to determine whether one state is immune in another state's courts.

The Act provides a broad immunity for nations, ${ }^{161}$ subject to several exceptions. ${ }^{162}$ The inajor exception is for actions arising out of a defendant's "commercial activity" having a nexus with the United States. ${ }^{163}$ The Act defines "commercial activity,"164 and the Act's legislative history includes some examples of commercial activity, but the legislative history concedes that the statutory definition is not "exces-

155. See Brandon, The Case Against the Restrictive Theory of Sovereign Immunity, 21 Ins. COUNSEL J. 11 (1954); Note, The Jurisdictional Immunity of Foreign Sovereigns, 63 YALE L.J. 1148, 1160-61 (1954). See also J. Sweeney, C. Oliver \& N. Leech, The INTERnational Legal SysTEM 311-13 (2d ed. 1981).

156. Letter from Jack B. Tate, supra note 114.

157. Republic of Mexico v. Hoffman, 324 U.S. 30, 34 (1945); Ex parte Republic of Peru, 318 U.S. 578, 589 (1943).

158. Act of Oct. 21, 1976, Pub. L. No. 94-583, 90 Stat. 2891-98 (amending 28 U.S.C. $\$ \$ 1332$, 1391,1441 (1970), and enacting 28 U.S.C. $\$ \$ 1330,1602-11$ (1970)).

159. H.R. REP. No. 1487, supra note 114, at 7, reprinted in [1976] U.S. CODE CoNG. \& AD NEws 6604, 6606; von Mehren, supra note 153, at 52 \& n.83.

160. See note 114 supra. See also vou Mehren, supra note 153, at 66. The United Kingdom, the last major noncommunist state to accept the restrictive theory, has recently passed comparable legislation concerning the immunity of foreign governments. See State Immunity Act, 1978, c. 33, reprinted in 17 INT'L LEGAL MATERIALs 1123 (1978). See generally Note, The Foreign Sovereign Immunities Act of 1976: Giving the Plaintiff His Day in Court, 46 FordHAM L. REv. 543 (1977); Note, Sovereign Immunity-Limits of Judicial Control-The Foreign Sovereign Immunities Act of 1976, 18 Harv. INT'L L.J. 429 (1977). See also Note, $A$ Comparative Analysis of the British State Immunity Act of 1978, 3 B.C. INT'L \& CoMP. L. REv. 175 (1979).

161. 28 U.S.C. $\$ 1604$ (1976).

162. Id. $\$ 1605$.

163. Id. \$ 1605(a)(2); H.R. REP. No. 1487, supra note 114, at 18-19, reprinted in [1976] U.S. Code CoNG. \& AD. News 6604, 6617-18.

164. Whether an activity is commercial is "determined by reference to the nature of the course of conduct or particular transaction or act, rather than by reference to its purpose." 28 U.S.C. $\S 1603$ (d) (1976). 
sively precise." 165 Congress contemplated that under the Act "[t]he courts would have a great deal of latitude in determining what is a "commercial activity." 166 Given the difficulty of making the distimction and the imprecision of the statutory definition, one might argue that the principles of the Foreign Sovereign Immunities Act should be limited to those cases to which the Act is expressly addressed-suits against foreign sovereigns. But as the courts will need to interpret the Act for purposes of foreign sovereigns in any case, ${ }^{167}$ there is no reason why the same or a similar body of precedents ${ }^{168}$ cannot be applied to interstate immunity.

The Act has other specific exceptions to immunity as well. The exceptions include cases in which the foreign state has waived its immunity ${ }^{169}$ and cases

in which money damages are sought against a foreign state for personal injury or death, or damage to or loss of property, occurring in the United States and caused by the tortious act or omission of that

165. H.R. REP. No. 1487, supra note 114, at 16, reprinted in [1976] U.S. CoDE CoNo. \& AD. NEws 6604, 6615; see Delaume, Public Debt and Sovereign Immunity: The Foreign Sovereign Immunities Act of 1976, 71 AM. J. INT'L L. 399, 404 (1977).

166. H.R. REP. No. 1487, supra note 114, at 16, reprinted in [1976] U.S. CODE CONO. \& AD. NEws 6604, 6615.

167. Recent cases interpreting the exceptions contained in the Act include Broadbeut v. OAS, 628 F.2d 27 (D.C. Cir. 1980) (immunity; the relationship of an international organization with its internal administrative staff is noncommercial); Avango v. Guzman Travel Advisors Corp., 621 F.2d 1371, 1378-80 (5th Cir. 1980) (tourists expelled from the Dominican Republic; immunity for false imprisonment and battery claims but no immumity for nonperformance of a contract for a vacation tour); United Euram Corp. v. USSR, 461 F. Supp. 609 (S.D.N.Y. 1978) (no immunity; contracting for the organizing of concerts under a cultural exchange agreement is "commercial activity"); Outboard Marine Corp. v. Pezetel, 461 F. Supp. 384, 394-96 (D. Del. 1978) (no immunity; antitrust violations may be "commercial activity"); National Am. Corp. v. Federal Rcpublic of Nigeria, 448 F. Supp. 622, 641-42 (S.D.N.Y. 1978) (uo immunity; the activity was commercial despite the military purpose of the contract), affd, 597 F.2d 314 (2d Cir. 1979); Yessenin-Volpin v. Novosti Press Agency, 443 F. Supp. 849 (S.D.N.Y. 1978) (immunity; publication of the assertcd defamatory stateinents by an official government press agency is not a "commercial activity").

Several cases have also dealt with whether concededly commercial activity lad a sufficient nexus with the United States. See, e.g., Sugarman v. Aeroinexico, Inc., 626 F.2d 270 (3d Cir. 1980) (no immunity); Carey v. National Oil Corp., 592 F.2d 673 (2d Cir. 1979) (immunity).

See generally Comment, Recent Developments in Anglo-American Doctrine of Foreign Sovereign Immunity, 5 INT'L TRADE L.J. 298, 312-17 (1980); Note, "Commercial Activity" in the Foreign Sovereign Immunities Act of 1976, 14 J. INT'L. L. \& ECON. 163 (1979).

168. The minnunity determinations of the Department of State between the time of the Tate letter, supra note 114, and the passage of the Foreign Sovereign Immunities Act have been indexed and inade public. J. Boyd, Digest of UNITED STATES PRACTICE IN INTERNATIONAL LAW 1017-89 (1977).

The Court is forced to nake distinctions between sovereign and nonsovereign functions in other contexts as well. See National Leagne of Cities v. Usery, 426 U.S. 833, $851-52$ (1976) (holding that federal minimum-wage laws may not be applied to states in ways that interfere with the states' capacity to perform their sovereign functions).

169. 28 U.S.C. $\$ 1605(a)(1)(1976)$. 
foreign state or of any official or employee of that foreign state while acting within the scope of his office or employment . . .170

This exception, though perhaps not as precise as it might be, ${ }^{171}$ was "directed primarily at the problem of traffic accidents,"172 and clearly would apply by analogy to the claim arising out of the traffic accident in Nevada $v$. Hall. The exception colnports with international law precedents; ${ }^{173}$ in fact, the plaintiffs in Nevada $v$. Hall argued that in the circumstances of a traffic accident "the State of Nevada does not carry with it any of the attributes of sovereignty nor exercise of governmental power." 174 The absence of sovereign functions, as defined by international law, is the soundest basis for the holding in Nevada v. Hall. International law balances a state government's interest in protecting and preserving its sovereignty against the interests of victims of a government tortfeasor who acts as a private individual might. Certainly in Nevada $v$. Hall the balance was in favor of the victim.

Some other case, however, could involve the state's "capacity to fulfill its own sovereign responsibilities," to use the language of the $\mathrm{Ne}$ vada v. Hall inajority's footnote. ${ }^{175}$ In such a case the state should be immune, and its immunity may logically be enforced by the apphication of international law principles. The principles may have to be modified because of the differences between the sovereignty of nations and the quasi-sovereignty of our states, ${ }^{176}$ but this necessary modification does not imply the absence of an enforceable immunity to protect the interests of a sovereign state to the extent that it does have sovereign responsibilities.

170. Id. $\$ 1605(\mathrm{a})(5)$. Excluded from the scope of these exemptions are claims based on the exercise of a discretionary function and for certain intentional torts. Id.

171. See Letelier v. Republic of Chile, 488 F. Supp. 665, 673 (D.D.C. 1980) (no immunity; political assassination is not within the discretionary function exclusion).

172. H.R. REP. No. 1487, supra note 114, at 20, reprinted in [1976] U.S. CoDE CoNG. \& AD. NEWS $6604,6619$.

173. See, eg., Collision with Foreign Government-Owned Motor Car, 40 I.L.R. 73 (Sup. Ct., Aus., 1961).

174. Brief for Respondents, supra note 147, at 9 . The plaintiffs argued both that the mere operation of an automobile does not amount to a sovereign function, and that the activity imvolved (the delivery of television parts) was not so important as to override California's interest in highway safety and in affording a reinedy for imjured residents. Id.

175. 440 U.S. at 424 n.24. An example might be a case involving a state-government employer-einployee dispute; $c f$. Broadbent v. OAS, 628 F.2d 27 (D.C. Cir. 1980) (dismissal of staff members of the OAS Secretariat is shielded by the doctrine of immunity).

176. For example, unlike sovereign states, states of the United States do not conduct diplomatic relations. See U.S. CoNST. art. I, \& 10. 


\section{Conclusion}

The international law of sovereign immunity now balances the interest of a sovereign state in avoiding undue interference with its governmental functions by other states with the interests of parties harmed by states acting indistinguishably from private persons. A similar balancing is needed with respect to the quasi-sovereign states of the United States. Such a balancing meets the concern of the majority in Nevada v. Hall of protecting the interests of the state in which the traffic accident occurred, without, as the dissent feared, eliminating a sound theoretical basis for limiting the holding. The theoretical basis, moreover, is not bound up with eleventh amendinent doctrines developed to allocate power between the federal government and the states rather than among the states theniselves. Instead it is based on the nature of our Union as a federation of quasi-sovereign states that, unlike most sovereign nations today, are subject to enforceable intersovereign rules of law by the court of a higher authority: the Supreme Court of the United States. 